\title{
Par Pond Vegetation Status Summer 1995 - September Survey Descriptive Summary
}

by

H. E. Mackey

Westinghouse Savannah River Company

Savannah River Site

Aiken, South Carolina 29808

R. S. Riley

DISTRIBUTION OF THIS DOCUMENT IS UNLIMHTED

DOE Contract No. DE-AC09-89SR18035

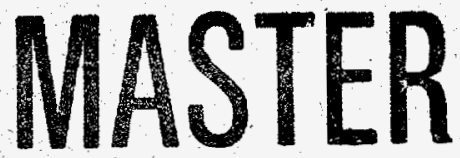

This paper was prepared in connection with work done under the above contract number with the U.S.

Department of Energy. By acceptance of this paper, the publisher and/or recipient acknowledges the U.S.

Government's right to retain a nonexclusive, royalty-free license in and to any copyright covering this paper, along with the right to reproduce and to authorize others to reproduce all or part of the copyrighted paper. 


\section{DISCLADMER}

Portions of this document may be illegible in electronic image products. Images are produced from the best available original document. 


\section{Par Pond Vegetation Status Summer 1995 September Survey Descriptive Summary}

Halkard E. Mackey, Jr. and R. S. Riley

Westinghouse Savannah River Company

Savannah River Technology Center

Environmental Sciences Section

Aiken, SC 29808

September 1995

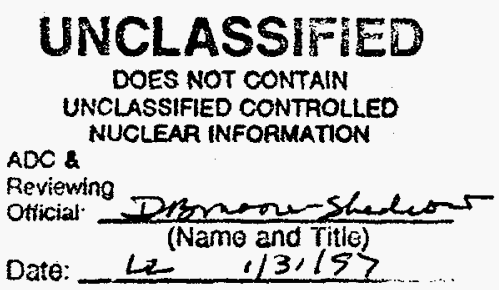

The information contained in this report was developed during the course of work with the U.S. Department of Energy under Contract No. DE-AC09-89SR18035. 


\section{DISCLAIMER}

This report was prepared as an account of work sponsored by an agency of the United States Government. Neither the United States Government nor any agency thereof, nor any of their employees, makes any warranty, express or implied, or assumes any legal liability or. -responsibility for the accuracy, completeness, or usefullness of any information, apparatus, product, or process disclosed, or represents that its use would not infringe privately owned rights. Reference herein to any specific commercial product, process, or service by trade name, trademark, manufacturer, or otherwise does not necessarily constitute or imply its endorsement, recommendation, or favoring by the United States Government or any agency thereof. The views and opinions of authors expressed herein do not necessarily state or reflect those of the United States Government or any agency thereof.

This report has been reproduced directly from the best available copy.

Available to DOE and DOE contractors from the Office of Scientific and Technical Information, P.O. Box 62, Oak Ridge, TN 37831; prices available from (615) 57.6-8401.

Available to the public from the National Technical-Information Service, U.S. Department of Commerce, 5285 Port Royal Road, Springfield, VA 22161. 


\section{Table of Contents}

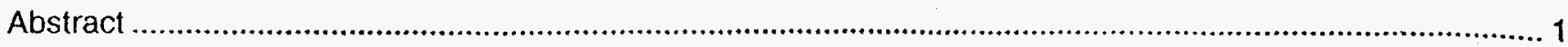

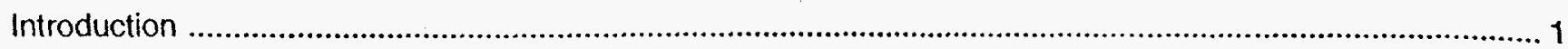

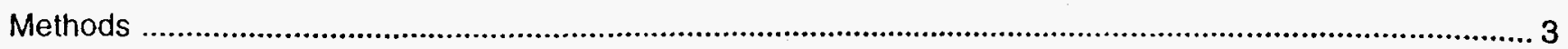

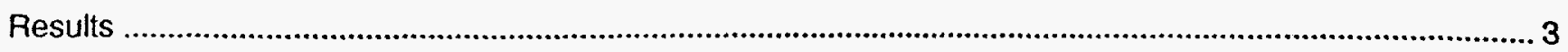

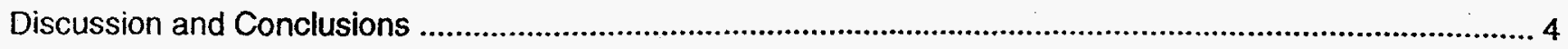

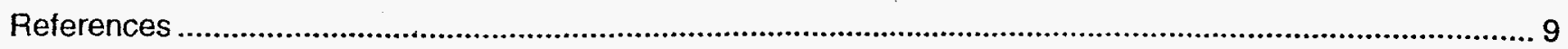

Appendix A Common and Scientific Names of Plants in this Report 


\section{List of Figures}

Figure 1.

Map of Par Pond marked with locations of transects

Figure 2.

Rate of Par Pond refill during winter and spring 1995. 4

Figure 3.

Woody species percent occurrence at the inner

zones of Par Pond transects. June, July, and September 1995 5

Figure 4.

Woody species percent occurrence at the outer zones

of Par Pond transects. June, July, and September 1995

Figure 5.

Herbaceous species percent occurrence at the inner zones

of Par Pond transects. June, July, and September 1995

Figure 6.

Herbaceous species percent occurrence at the outer zones

of Par Pond transects. June, July, and September 1995

Figure 7.

Herbaceous species percent cover at the inner zones

of Par Pond transects. June, July, and September 1995 7

Figure 8.

Herbaceous species percent cover at the outer zones

of Par Pond transects. June, July, and September 1995 


\title{
Par Pond Vegetation Status Summer 1995- September Survey Descriptive Summary
}

\author{
Halkard E. Mackey, Jr. and R. S. Riley \\ Westinghouse Savannah River Company \\ Savannah River Technology Center \\ Environmental Sciences Section \\ Aiken, SC 29808
}

\begin{abstract}
A survey of the emergent shoreline aquatic plant communities, begun in June 1995, three months after the refilling of Par Pond to approximately 200 feet (61 meters) above mean sea level, was repeated in July and continued with this mid-September survey. Aquatic plant communities similar to the predrawdown Par Pond communities are becoming reestablished. Beds of maidencane (Panicum hemitomon), lotus (Nelumbo lutea), water lily (Nymphaea odorata), and watershield (Brasenia schreberi) are now extensive and well established. Cattail (Typha spp.) occurrence continues to increase, but large beds common to Par Pond prior to the drawdown have not formed. Future surveys are planned for the late growing season of 1995 throughout 1996 and 1997, and for evaluation of satellite data to map the areal extent of the macrophyte beds of Par Pond.
\end{abstract}

\section{Introduction}

Par Pond, a 2500-acre (1012-hectare) cooling water reservoir on the Savannah River Site (SRS), was created in 1958 by constructing an earthen dam across the upper reaches of the Lower Three Runs drainage system (Figure 1) (Wilde and Tilly 1985). Par Pond served as a recirculating, cooling water reservoir for R-Reactor until 1963 and for P-Reactor from 1961 until 1988. P-Reactor operated approximately $70 \%$ of the time prior to 1988 . During the summer, the temperatures of the water entering Par Pond from Pond $\mathrm{C}$ ranged from 72 to $108^{\circ} \mathrm{F}\left(22\right.$ to $\left.42^{\circ} \mathrm{C}\right)$ (Jones et al. 1979). Maximum shoreline water temperatures in the vicinity of the hot dam ranged from 90 to $95^{\circ} \mathrm{F}$ ( 32 to $35^{\circ} \mathrm{C}$ ) (Liu et al. 1978). The thermal effluent cooled rapidly as it dispersed primarily through the southern half of the reservoir (Ezra and Tinney 1985). The north and west arms of Par Pond had temperatures at, or only slightly above, typical lake temperatures for the region (Liu et al. 1978).
The water level of Par Pond remained relatively stable, fluctuating typically less than 0.5 foot $(0.15$ meter) in most years. Natural invasion of macrophytes in the lake and along the shoreline occurred over the 33-year history of the lake, until mid-1991, when Par Pond was lowered from 200 feet (61 meters) above mean sea level (MSL) to 181 feet (55 meters) above MSL in about a two-month period. Lowering the water level was deemed necessary to protect downstream residents from possible dam failure suggested by subsidence on the downstream slope of the dam. Prior to lowering in 1991, Par Pond was bordered by extensive beds of persistent and nonpersistent aquatic macrophytes. These beds often exceeded 66-131 feet (2040 meters) in width (shoreline to deep water) and in several areas exceeded 328 feet (100 meters). For example, from 1988, 1989, and 1990 SPOT satellite data, it was estimated that along the shoreline of Par Pond, 474 acres (192 hectares) of cattails (Typha sp.) or persistent emergent macrophytes were present during the 1988 growing season, 442 acres ( 179 hectares) during 1989, and 432 


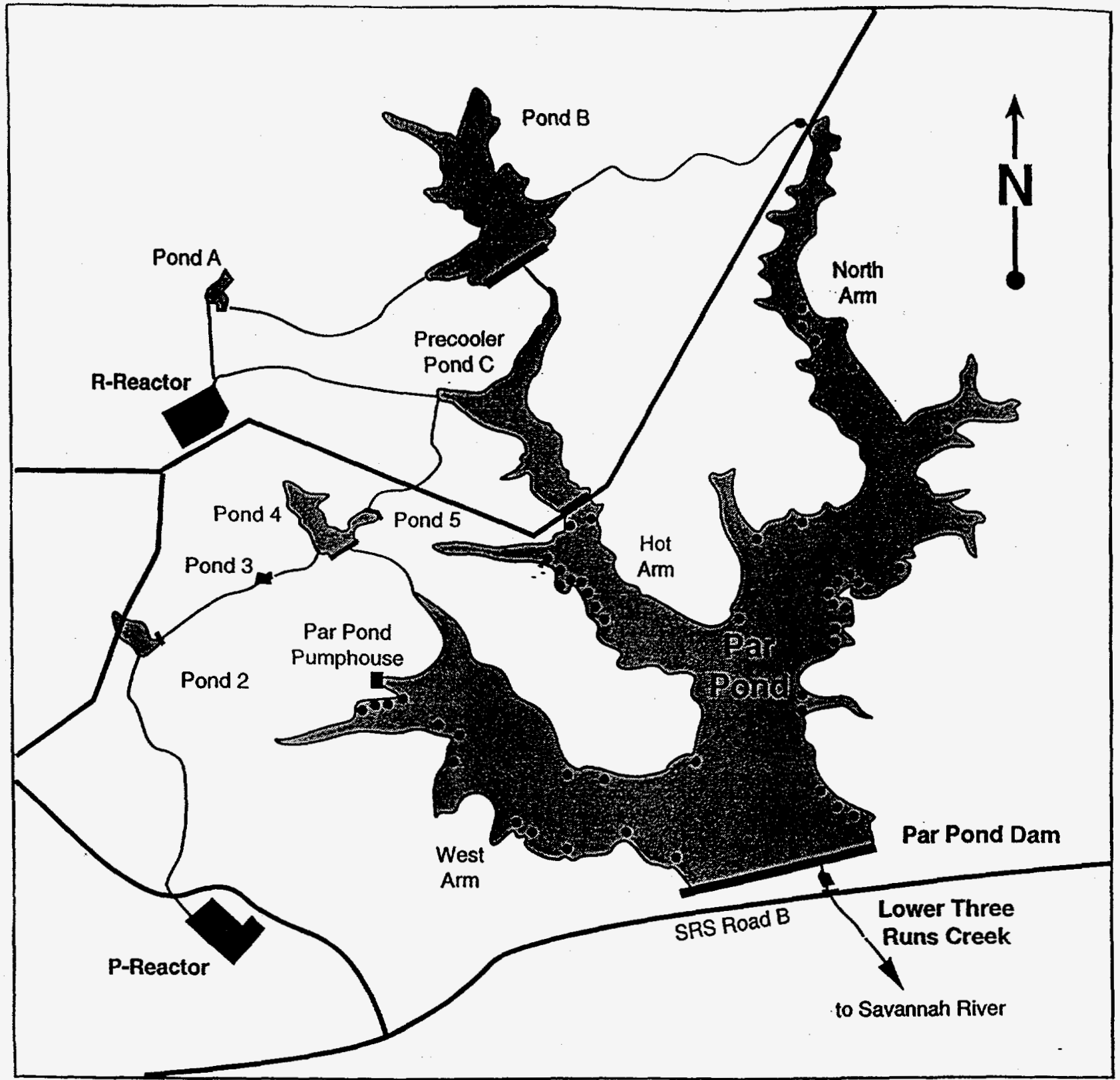

Figure 1. Map of Par Pond marked with locations of transects.

acres (175 hectares) during 1990. There were 371 acres (150 hectares) of water lilies (Nymphaea odorata) or other nonpersistent macrophytes in 1988, 311 acres (126 hectares) in 1989, and 368 acres (149 hectares) in 1990 (Narumalani 1993).

In 1987, 62 transects were established along the shoreline of Par Pond (Jensen et al. 1991, 1992a, 1992b, 1993; Jensen and Mackey 1991; Narumalani 1993). The dominate aquatic macro- phyte patterns were recorded each spring (April or May) and fall (September or October) from 1988 through June 1991, just prior to the lowering of the Par Pond water level. In these previous studies, the major species present in both the persistent (emergent, i.e., cattails) and nonpersistent (floating-leafed, i.e., water lily, lotus [Nelumbo lutea]) macrophyte categories were recorded, along with the width of each bed along the transects and estimates of percent cover by species at each 
transect. Spring and fall SPOT satellite data also were collected and analyzed for the 1988-1991 time period to provide estimates of area of coverage by major aquatic macrophyte category for the lake. These methods and data are summarized in the above mentioned references.

Beginning in June 1991, Par Pond was lowered from 200 feet (61 meters) above MSL to 181 feet (55 meters) above MSL. This lowering was sufficient to expose both the emergent and nonemergent macrophyte beds of the Par Pond shoreline to drying conditions; therefore, extensive macrophyte losses occurred. Initial surveys in August 1992 by F. W. Whicker (Personal communication, Savannah River Ecology Laboratory) indicated some reinvasion on the newly exposed shoreline. Plänt succession was occurring on about $65 \%$ of the exposed lake bed with approximately $35 \%$ still barren. Grasses, sedges, and rushes were the dominant forms with a mixture of old-field species, including dog-fennel (Eupatorium sp.) and loblolly pine (Pinus taeda), which became more evident after spring 1993. In isolated pockets within coves of Par Pond, sufficient groundwater seepage or inflow from small streams allowed remnants of the $\mathrm{Par}$ Pond macrophyte communities to survive (e.g., beds of water lilies in the cove south of the Par Pond pump house [Figure 1]) as evident in late April 1995 vertical aerial photography. In midOctober 1994, after dam repairs were completed, the U.S. Department of Energy initiated the refill of Par Pond and by mid-March 1995, Par Pond approached its former full pool level of approximately 200 feet (61 meters) above MSL (Figure 2). The Par Pond water level has remained relatively constant since refill, fluctuating about 0.4 foot ( 0.12 meter).

\section{Methods}

Of the 62 transects along the Par Pond shoreline in June 1991, 48 were relocated in March 1995. Descriptive notes on the vegetation patterns at each transect were taken beginning in June 1995 to in- dicate the condition of any standing vegetation following refill and initial regrowth of macrophyte communities (Mackey and Riley 1995a, 1995b). Photographs of each transect were taken in June 1995. The transects were revisited in July 1995 and photographed. The most recent survey was conducted in September 1995, and the transects were again photographed. The species present were recorded along with a nominal estimate of percent cover for any species appearing to occupy more than a "trace" (less than $0.1 \%$ of the water surface) (Phillips 1959; Mueller-Dombois and Ellenberg 1974). Two zones (an inner and an outer zone) were characterized on both surveys. Both zones started at the location pole of the transect marker used in 1988-1991 surveys to mark the boundary between the persistent emergent aquatic beds (i.e., primarily cattails, spike rush [Eleocharis sp.]) and the nonpersistent floating-leafed macrophytes beds (i.e., water lilies and lotus). The inner zone extended from the transect shoreward and the outer zone extended from the transect to deeper water. Water depth at the transect marker averaged approximately 3.3 feet ( 1 meter) in previous surveys (Jensen et al. 1991, 1992a, 1992b, 1993; Jensen and Mackey 1991; Narumalani 1993).

\section{Results}

Since the refilling of Par Pond, most of the oldfield species that invaded much of the exposed shoreline are now absent. For example, all the loblolly pines which were growing in both the outer and inner transect zones have died, except for those in the very shallow areas along the shoreline (Figures 3 and 4; See Appendix A for common and scientific names of the plants). The most common woody species along the Par Pond shoreline before refill were newly invaded willow (Salix spp.) and red maple (Acer rubrum), but even these more flood-tolerant species are showing indications of stress and mortality from the continued flooding over the past six months (Figures 3 and 4). 


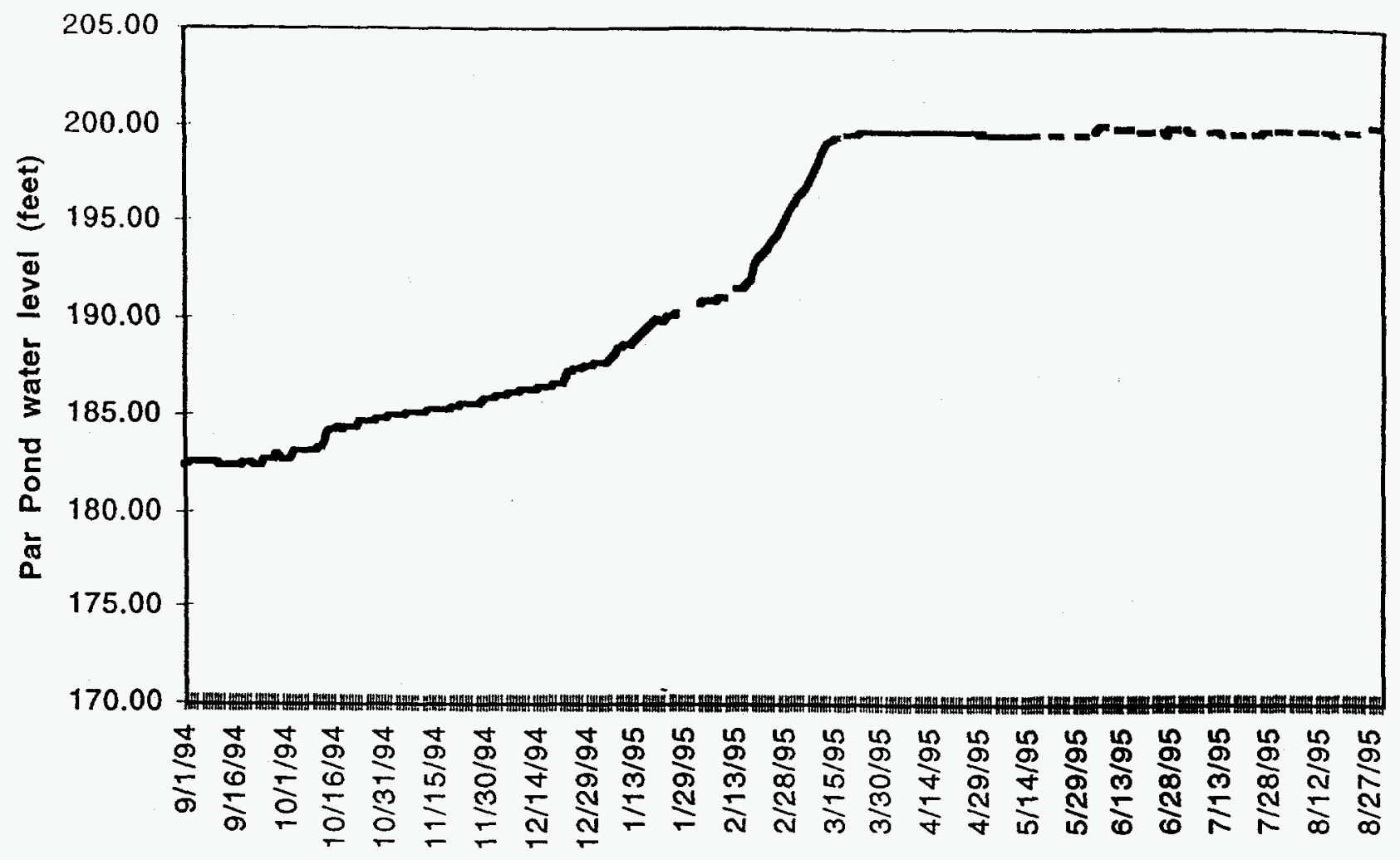

Figure 2. Rate of Par Pond refill during winter and early spring of 1995.

Maidencane (Panicum hemitomon) continues to be the most common macrophyte species along the shoreline, but lotus, water lily, and watershield (Brasenia schreberi) continued to increase between the mid-June and mid-September surveys (Figures 5 and 6 ). The increase in occurrence of these three species of macrophytes may represent widespread seed dispersion and availability from previous years. Figures 5 and 6 summarize estimates of herbaceous species percent occurrence (number of transects in which a species occurred divided by the total number of transects) at the inner and outer zones of Par Pond transects. Figures 7 and 8 summarize percent cover at the inner and outer zones of Par Pond transects for the most common herbaceous species observed at the transects during the June, July, and September 1995 surveys.

\section{Discussion and Conclusions}

The shoreline aquatic vegetation of Par Pond is undergoing rapid redevelopment. Maidencane percent occurrence and percent cover did not change much among the June, July, and September surveys. Other dominant species that occurred in Par Pond prior to the drawdown continue to increase, especially lotus, water lily, watershield, and spike-rush. Cattails are present, but remain widely scattered; no major beds have developed to date. Small isolated beds of cattails (approximately 3 to 7 feet [ 1 to 2 meters] wide and 6 to 33 feet [ 5 to 10 meters] long) are forming along the original shoreline of Par Pond. However, most areas occupied by cattails prior to the drawdown are currently dominated by maidencane or remain as open water with occasional lotus, water lily, and watershield present. The water level in Par Pond for the first five months following refill has fluctuated about 0.6 foot ( 0.2 meter). This fluctuation may be the reason that a small band of primrose (Ludwigia sp.) has developed along areas of exposed shoreline. A similar band was observed at $L$ Lake for the first few years after L Lake was filled in 1985. The woody species such as loblolly pine, red map! 


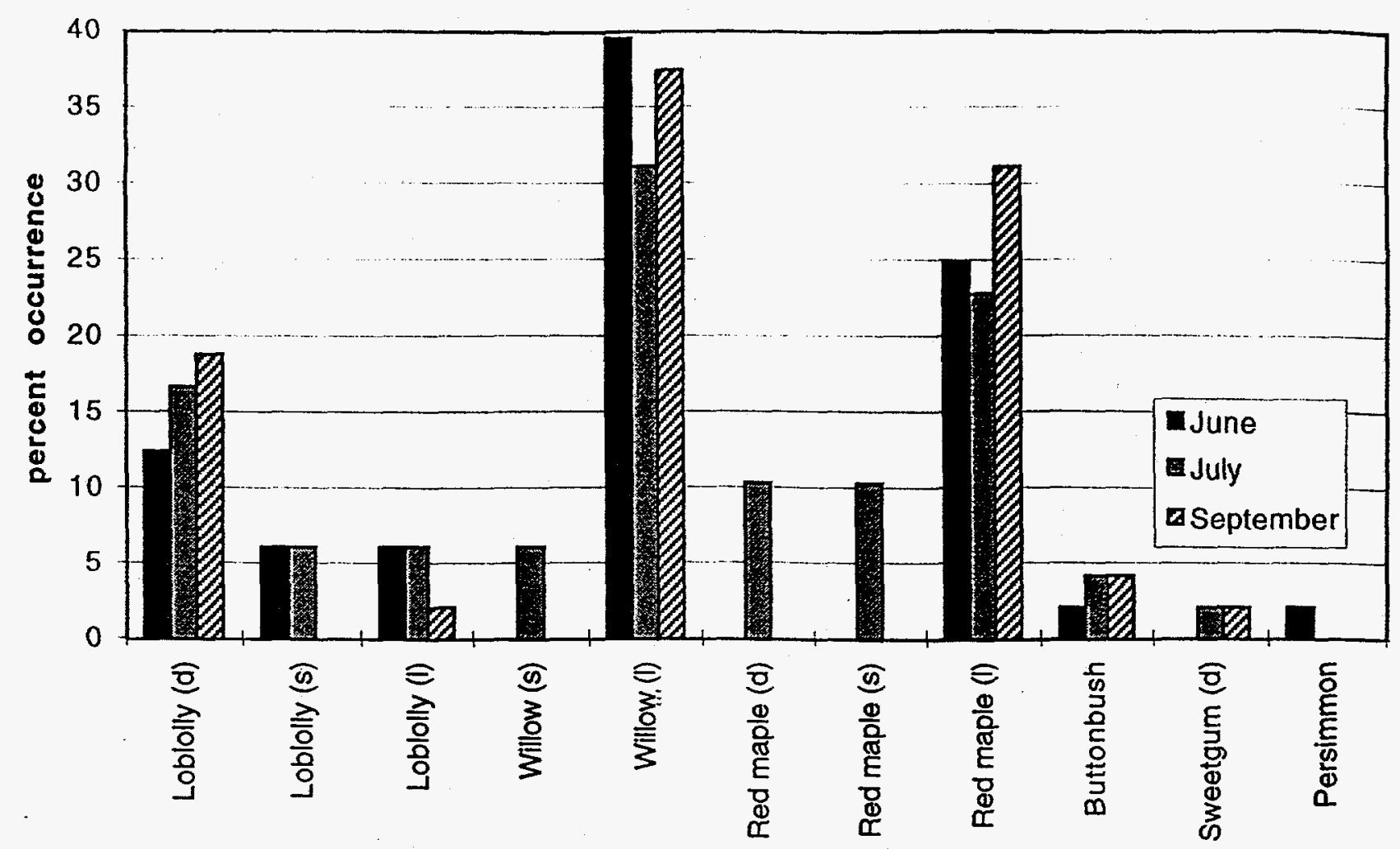

Figure 3. Woody species percent occurrence at the inner zones of Par Pond transects $[(d)=$ dead; $(s)=$ stress; $(1)=$ living]. June, July, and September 1995.

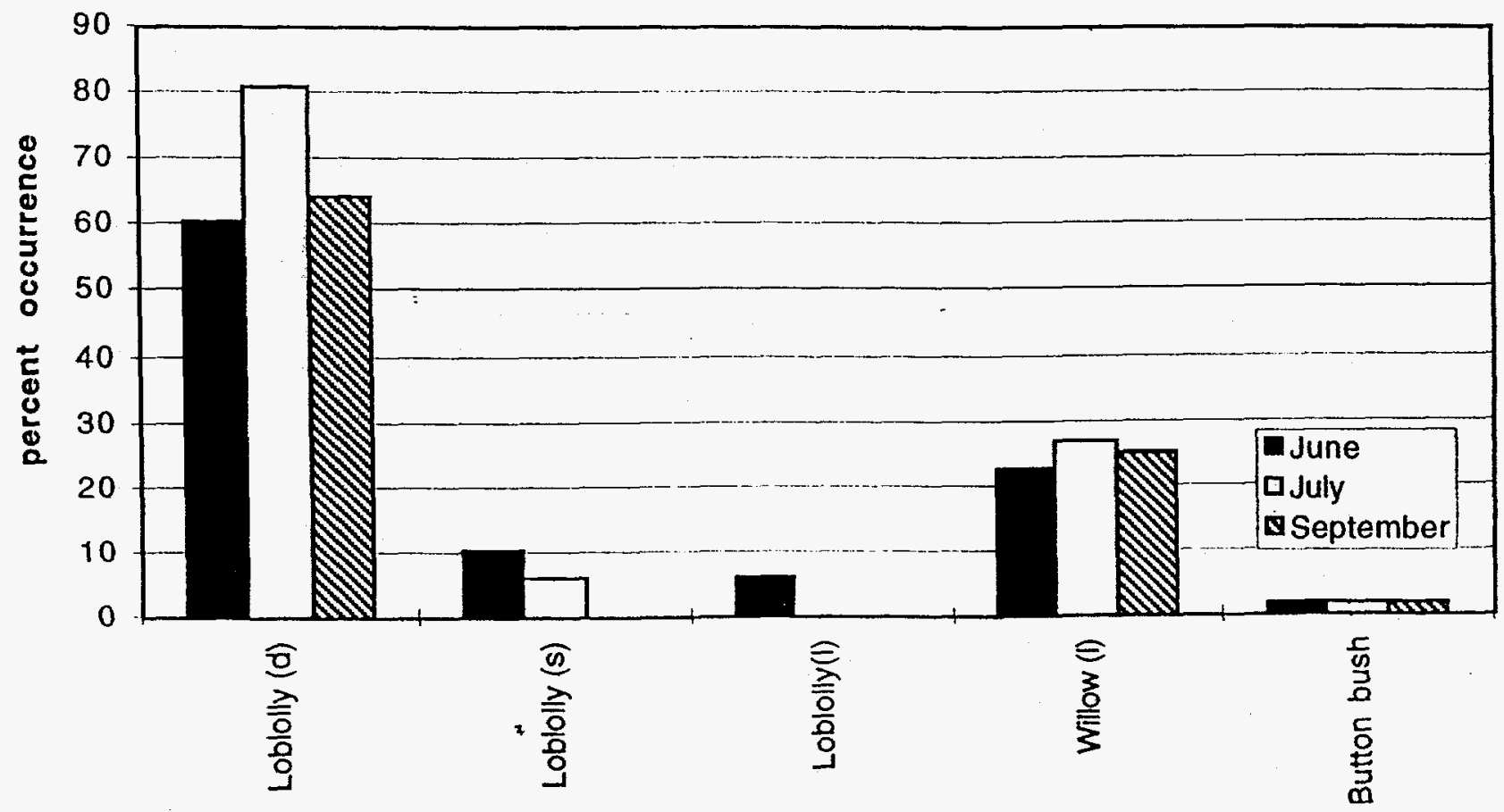

Figure 4. Woody species percent occurrence in the outer zones of Par Pond transects $[(d)=$ dead; $(s)=$ stress; (1) = living]. June, July, and September 1995. 


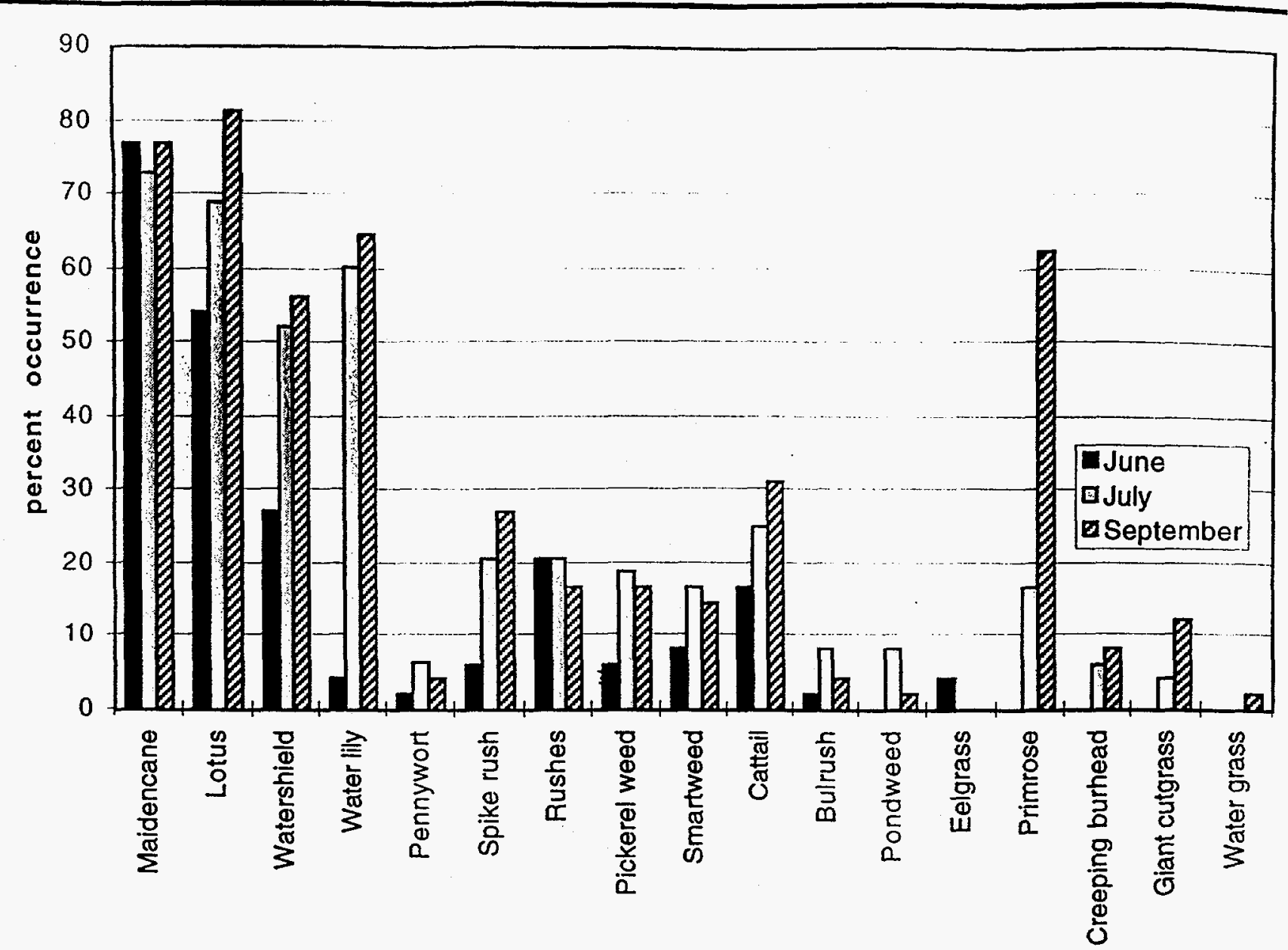

Figure 5. Herbaceous species percent occurrence at the inner zones of Par Pond transects. June, July, and September 1995.

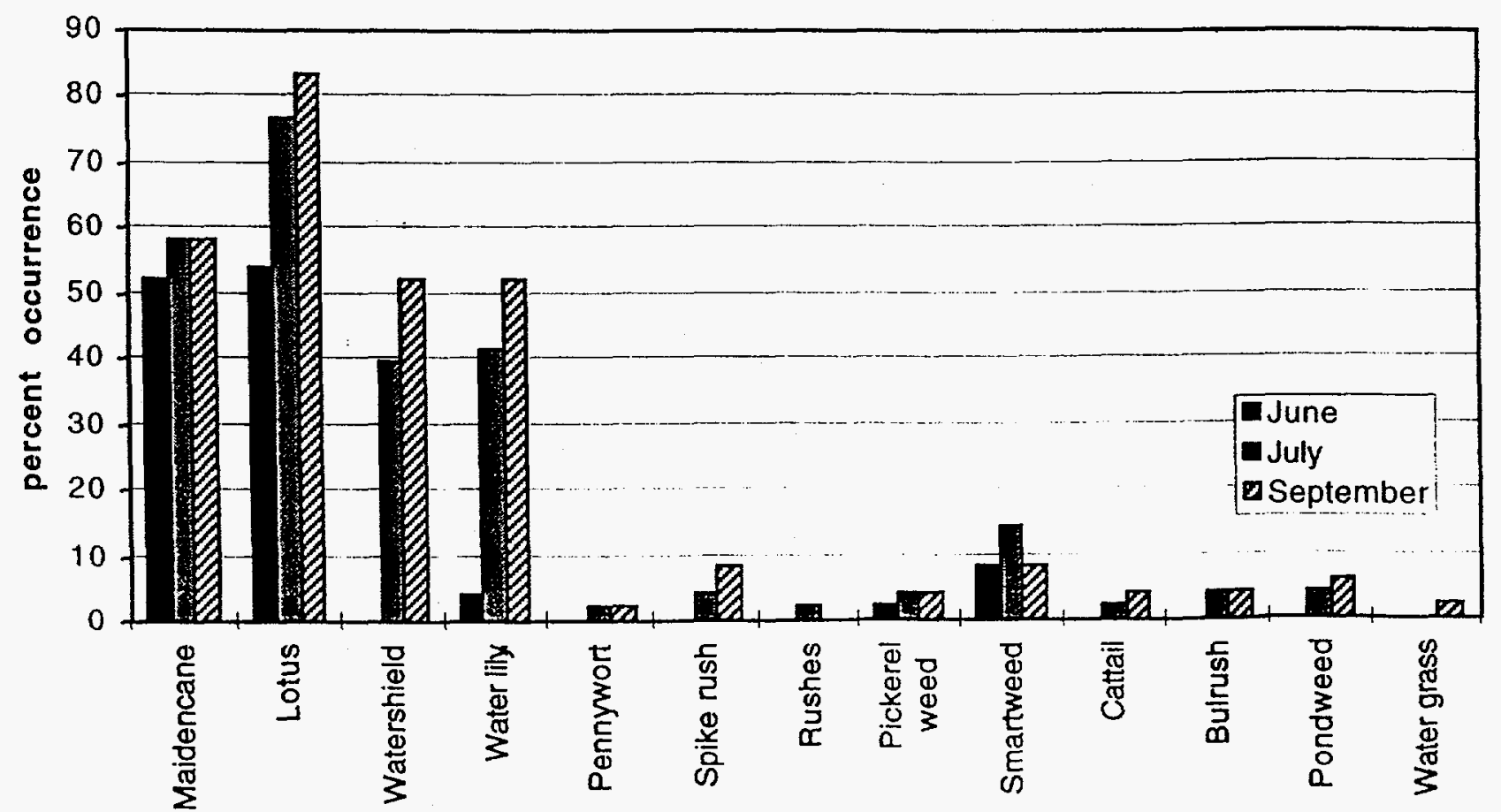

Figure 6. Herbaceous species percent occurrence at the outer zones of Par Pond transects: June, July, and September 1995. 


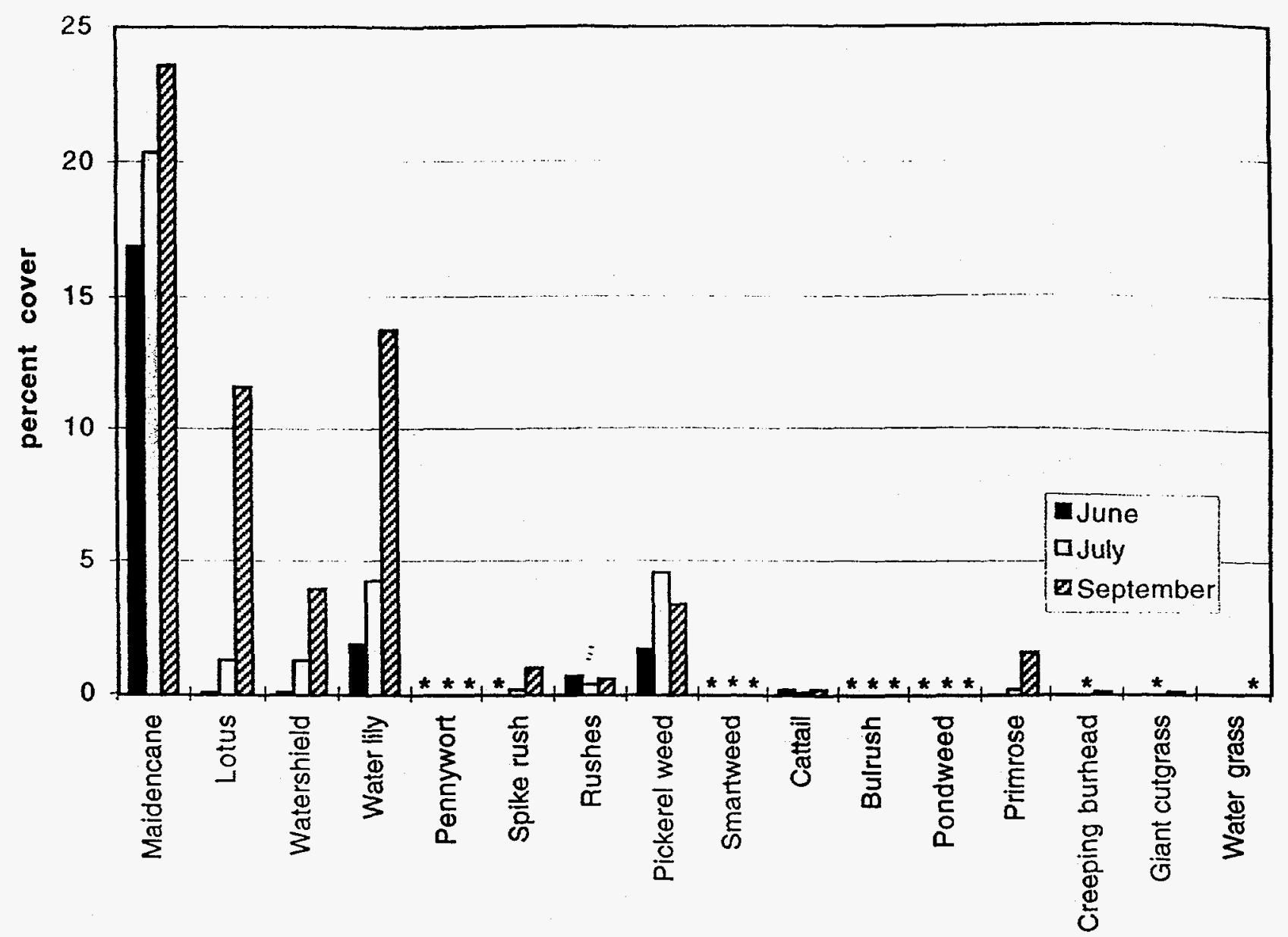

Figure 7. Herbaceous species percent cover at the inner zones of Par Pond transects. * Species with less than 0.05 percent cover: pennywort, spikerush, smartweed, bulrush, and pondweed in June; pennywort, smartweed, bulrush, pondweed, creeping burhead, and giant cutgrass in July; pennywort, smartweed, bulrush, pondweed, and watergrass in September. June, July, and September 1995.

and willow are declining following the refill of Par good evidence of the likely direction the Par Pond Pond. These early surveys are already providing communities will take in their development. 


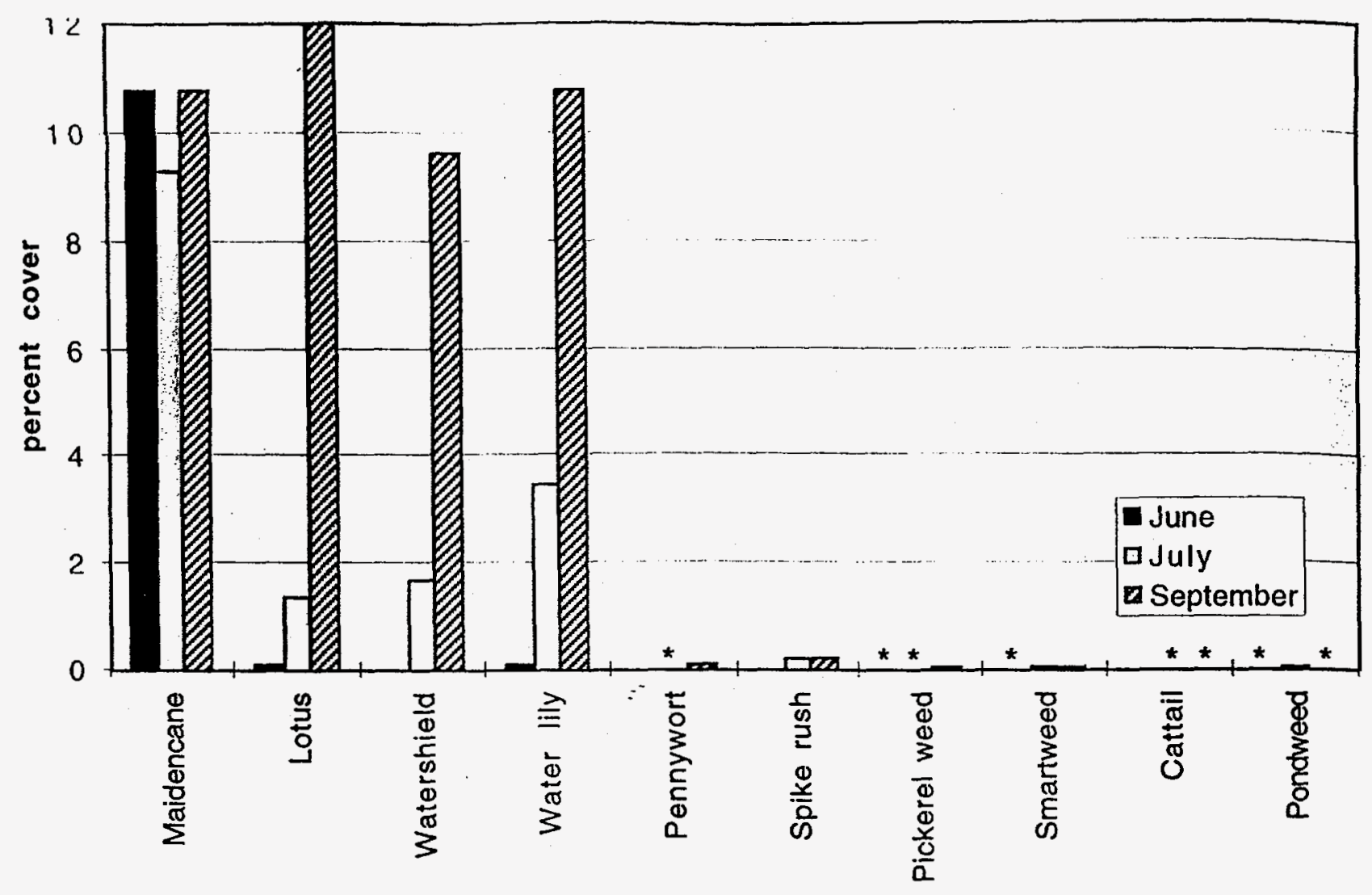

Figure 8. Herbaceous species percent cover in the outer zones of Par Pond transects. * Species with less than 0.05 percent cover: pickerel weed, smartweed, and pondweed in June; pennywort, pickerel weed, cattail in July; cattail and pondweed in September. June, July, and September 1995. 


\section{References}

Ezra, C. E. and L. R. Tinney. 1985. Par Pond Macrophyte Study Savannah River Plant, Aiken, South Carolina. EG\&G/EM Letter Report DOE (ONSSRL) 8513.

Jensen, J. R., and H. E. Mackey, Jr. 1991. Remote Sensing of Freshwater Aquatic Macrophytes in a Southeastern Lake: Part 1-Analysis of 30 Years of Vertical Aerial Photography. Volume 3. Remote Sensing. Proceeding of the 1991 ACSM-ASPRSAnnual Convention. Baltimore, MD. pp 224-231.

Jensen, J. R., S. Narumalani, O. Weatherbee, and H. E. Mackey, Jr. 1991. Remote Sensing Offers an Alternative for Mapping Wetlands. Geo Info Systems. October, 1991. pp. 48-53.

Jensen, J. R., S. Narumalani, O. Weatherbee, and H. E. Mackey, Jr. 1992a. Measurement of Seasonal and Yearly Macrophyte Changes in a Reservoir Using Multidate SPOT Panchromatic Data. Proceedings 1992 ASPRS-ACSM Annual Convention, Albuquerque, NM, pp. 167-176.

Jensen, J. R., S. Narumalani, O. Weatherbee, K. S. Morris, Jr., and H. E. Mackey, Jr. 1992b. Predictive Modeling of Cattail and Waterlily Distribution in a South Carolina Reservoir Using GIS." Photogrammetric Engineering \& Remote Sensing 58(11):1561-1568.

Jensen, J. R., S. Narumalani, O. Weatherbee, and H. E. Mackey, Jr. 1993. Measurement of Seasonal and Yearly Cattail and Waterlily Changes Using Multidate SPOT Panchromatic Data. Photogrammetric Engineering \& Remote Sensing $9(4): 519-525$.

Jones, J. C., J. F. Hancock, and'E. H. Liu. 1979. Biochemical and Morphological Effects of Tem- perature on Typha latifolia L. (Typhaceae) Originating from Different Ends of a Thermal Gradient. I. Controlled Environmental Studies. American Journal of Botany 66(8):902-906.

Liu, E. H., R. R. Sharitz, and M. H. Smith, 1978. Thermal Sensitivities of Malate Dehydroganase Isozymes in Typha. American Journal of Botany 65(2):214-220.

Mackey, H. E., Jr., and R. S. Riley. 1995a. Par Pond Vegetation Status Summer 1995 - June Survey, Descriptive Summary. WSRC-RP-95-0854, Westinghouse Savannah River Company, Aiken, $\mathrm{SC}$.

Mackey, H. E., Jr., and R. S. Riley. 1995b. Par Pond Vegetation Status Summer 1995-July Survey, Descriptive Summary. WSRC-RP-95-0720, Westinghouse Savannah River Company, Aiken, $\mathrm{SC}$.

Narumalani, S. 1993. Classification and Modeling of Aquatic Macrophytes Using Remote Sensing and Geographic Information Systems. Ph.D. dissertation, Department of Geography, University of South Carolina, Columbia, SC. $105 \mathrm{pp}$.

Mueller-Dombois, D. and H. Ellenberg. 1974. Aims and Methods of Vegetation Ecology. John Wiley \& Sons, Inc. New York, NY. 547 pp.

Phillips, E. A. 1959. Methods of Vegetation Study. Holt, Rinehart and Winston, Inc., New York, NY. 107 pp.

Wilde, E. W. and L. J. Tilly. 1985. Influence of PReactor Operation on the Aquatic Ecology of Par Pond-A Literature Review. DP-1698, E. I. du Pont de Nemours and Company, Savannah River Laboratory, Aiken, SC. 


\section{Appendix A}

\section{Common and Scientific Names of Plants in this Report}

\begin{tabular}{llll} 
Common Name & Sclentific Name & Common Name & Scientific Name \\
\hline bulrush & Scirpus sp. & pickerel weed & Pontederia cordata \\
button bush & Cephalanthus occidentalis & poke berry & Phytolacca americana \\
briars & Rubus spp. & pond weed & Potamogeton sp. \\
broom sedge & Andropogon virginicus & primrose & Ludwigia sp. \\
cattail & Typha spp. & red maple & Acer rubrum \\
creeping burhead & Echinodorus sp. & rush & Juncus spp. \\
dog fennel & Eupatorium sp. & smartweed & Polygonum sp. \\
eelgrass & Vallisneria sp. & spike-rush & Eleocharis sp. \\
giant cutgrass & Zizaniopsis sp. & sweetgum & Liquidambar styraciflua \\
loblolly pine & Pinus taeda & water grass & Hydrochloa sp. \\
lotus & Nelumbo lutea & water lily & Nymphaea odorata \\
maidencane & Panicum hemitomon & watershield & Brasenia schreberi \\
pennywort & Hydroctyle sp. & willow & Salix sp. \\
persimmon & Diospyros virginiana & & \\
\hline
\end{tabular}

